\title{
AMPA Receptor Activates a G-Protein that Suppresses a cGMP-Gated Current
}

\author{
Fusao Kawai ${ }^{1,2}$ and Peter Sterling ${ }^{1}$ \\ ${ }^{1}$ Department of Neuroscience, University of Pennsylvania, Philadelphia, Pennsylvania 19104-6058, and ${ }^{2}$ Department of \\ Information Physiology, National Institute for Physiological Sciences, Okazaki 444, Japan
}

\begin{abstract}
The AMPA receptor, ubiquitous in brain, is termed "ionotropic" because it gates an ion channel directly. We found that an AMPA receptor can also modulate a G-protein to gate an ion channel indirectly. Glutamate applied to a retinal ganglion cell briefly suppresses the inward current through a cGMP-gated channel. AMPA and kainate also suppress the current, an effect that is blocked both by their general antagonist CNQX and also by the relatively specific AMPA receptor antagonist GYKI52466. Neither NMDA nor agonists of metabotropic glutamate receptors are effective. The AMPA-induced suppression of the cGMP-gated current is blocked when the patch pipette in-
\end{abstract}

Glutamate, the major excitatory transmitter in brain, activates a class of receptors termed "ionotropic" because they directly gate ion channels (Nakanishi, 1992; Seeburg, 1993; Hille, 1994; Riedel, 1996; Pass, 1998). Recently, an ionotropic glutamate receptor of the subclass that binds AMPA was discovered in cortical homogenates to also have a "metabotropic" function: it activates a G-protein to suppress adenylyl cyclase (Wang et al., 1997). We wondered whether the AMPA receptor has other metabotropic functions and whether these might include indirect gating of ion channels. We thought to probe for a metabotropic effect in a system suited for subsequent investigation of its role in neural integration.

We chose the retinal ganglion cell because the effects of stimulating its dendritic AMPA receptors can be investigated in a slice preparation (Aizenman et al., 1988; Mittman et al., 1990; Cohen et al., 1994; Leinders-Zufall et al., 1994; Taylor et al., 1995; Zhang et al., 1995; Coleman and Miller, 1998; Matsui et al., 1998) and because the role in neural integration could then be investigated in the intact retina in vitro. Certain ganglion cells express a cGMP-gated channel that causes an inward current when nitric oxide (NO) stimulates guanylyl cyclase to raise [cGMP] (Ahmad et al., 1994). The natural source of NO is probably a class of amacrine cell that stains intensely for NADPH diaphorase (NO synthase) (Sandell, 1985; Sager, 1986). Reasoning that a current stimulated by one signal (NO) ought to be antagonized by another, we tested the AMPA receptor and

\footnotetext{
Received Dec. 16, 1998; revised Feb. 1, 1999; accepted Feb. 3, 1999.

This work was supported by National Institutes of Health Grant EY00828. We thank N. Vardi, S. Zigmond, P. Liebman, D. Manning, S. Nawy, and A. Kaneko for comments; R. Smith, M. Freed, L. Haarsma, J. Demb, and J. Tanaka for technical advice; and S. Watanabe for technical advice on the slice preparation.

Correspondence should be addressed to Dr. Fusao Kawai, c/o Dr. Peter Sterling, 123 Anatomy/Chemistry Building, Department of Neuroscience, School of Medicine, University of Pennsylvania, Philadelphia, PA 19104-6058.

Copyright (C) 1999 Society for Neuroscience $0270-6474 / 99 / 192954-06 \$ 05.00 / 0$
}

cludes GDP- $\beta$-S, whereas the suppression is irreversible when the pipette contains GTP- $\gamma$-S. This suggests a G-protein mediator, and, consistent with this, pertussis toxin blocks the current suppression. Nitric oxide (NO) donors induce the current suppressed by AMPA, and phosphodiesterase inhibitors prevent the suppression. Apparently, the AMPA receptor can exhibit a "metabotropic" activity that allows it to antagonize excitation evoked by NO.

Key words: AMPA; glutamate; ionotropic; metabotropic; Gprotein; retina; rat

discovered that in retinal ganglion cells it can activate a G-protein to suppress the cGMP-gated current.

\section{MATERIALS AND METHODS}

Preparation and recording. Slices from adult rat retina were cut at $200 \mu \mathrm{m}$ (Werblin, 1978) and viewed on a Zeiss (Oberkochen, Germany) upright microscope with differential interference contrast optics ( $\times 40$ waterimmersion objective). Ganglion cells were identified in the slice by their position and size. Membrane currents were recorded in the whole-cell configuration (Hamill et al., 1981) using a patch-clamp amplifier (Axopatch 200A; Axon Instruments, Foster City, CA) linked to a computer. The voltage-clamp procedures were controlled by the pClamp software (Axon Instruments). Data were low-pass filtered (four-pole Bessel type) with a cutoff frequency of $5 \mathrm{kHz}$ and then digitized at $10 \mathrm{kHz}$ by an analog-to-digital interface. All experiments were performed at room temperature $\left(23-25^{\circ} \mathrm{C}\right)$.

Solutions and drugs. The control Ringer's solution contained (in mM): $\mathrm{NaCl}, 135 ; \mathrm{KCl}, 5 ; \mathrm{CaCl}_{2}, 1 ; \mathrm{MgCl}_{2}, 1$; HEPES, 10 ; and glucose, 10 . The solution was adjusted with $\mathrm{NaOH}$ to $\mathrm{pH} 7.4$ and bubbled with oxygen. $\mathrm{CoCl}_{2}(1 \mathrm{mM})$, picrotoxin $(100 \mu \mathrm{M})$, and strychnine $(1 \mu \mathrm{M})$ were also added to block synaptic transmission. The recording pipette contained (in mM): $\mathrm{CsCl}, 140$; $\mathrm{CaCl}_{2}, 1$; EGTA or BAPTA, 5; HEPES, 10; and $\mathrm{Mg}$-ATP, 2. The solution was adjusted with $\mathrm{CsOH}$ to $\mathrm{pH}$ 7.4. Pipette resistance was $\sim 7 \mathrm{M} \Omega$.

Test substances were applied through the bath [8-bromo-cGMP, 8-bromo-cAMP, 8-p-chlorophenylthio-cGMP, CNQX, GYKI-52466, $\alpha$-methyl-4-caboxyphenylglycine (MCPG), $\alpha$-cyclopropyl-4-phosphonophenylglycine (CPPG), 1-methyl-3-isobutylxanthine (IBMX), zaprinast, methylene blue, or sodium nitroprusside], via pressure ejection for $1 \mathrm{sec}$ from a "puffer" pipette (glutamate, AMPA, kainate, NMDA, L-2-amino-4-phosphonobutyrate [L-AP-4], or $1 S, 3 R$-1-aminocyclopentane-trans-1,3-dicarboxylic acid [trans-(1S,3R)-ACPD]), or via the patch pipette (cGMP, GTP- $\gamma$-S, GDP- $\beta$-S, pertussis toxin, or cholera toxin). MCPG and CPPG were purchased from Tocris Cookson (Ballwin, MO). Other chemicals were from Sigma (St. Louis, MO).

\section{RESULTS}

Recording from ganglion cells in the slice preparation of adult rat retina, we confirmed the observations of Ahmad et al. (1994) that certain ganglion cells express a cGMP-gated current. When a membrane-permeant analog of cGMP (8-bromo-cGMP) was 

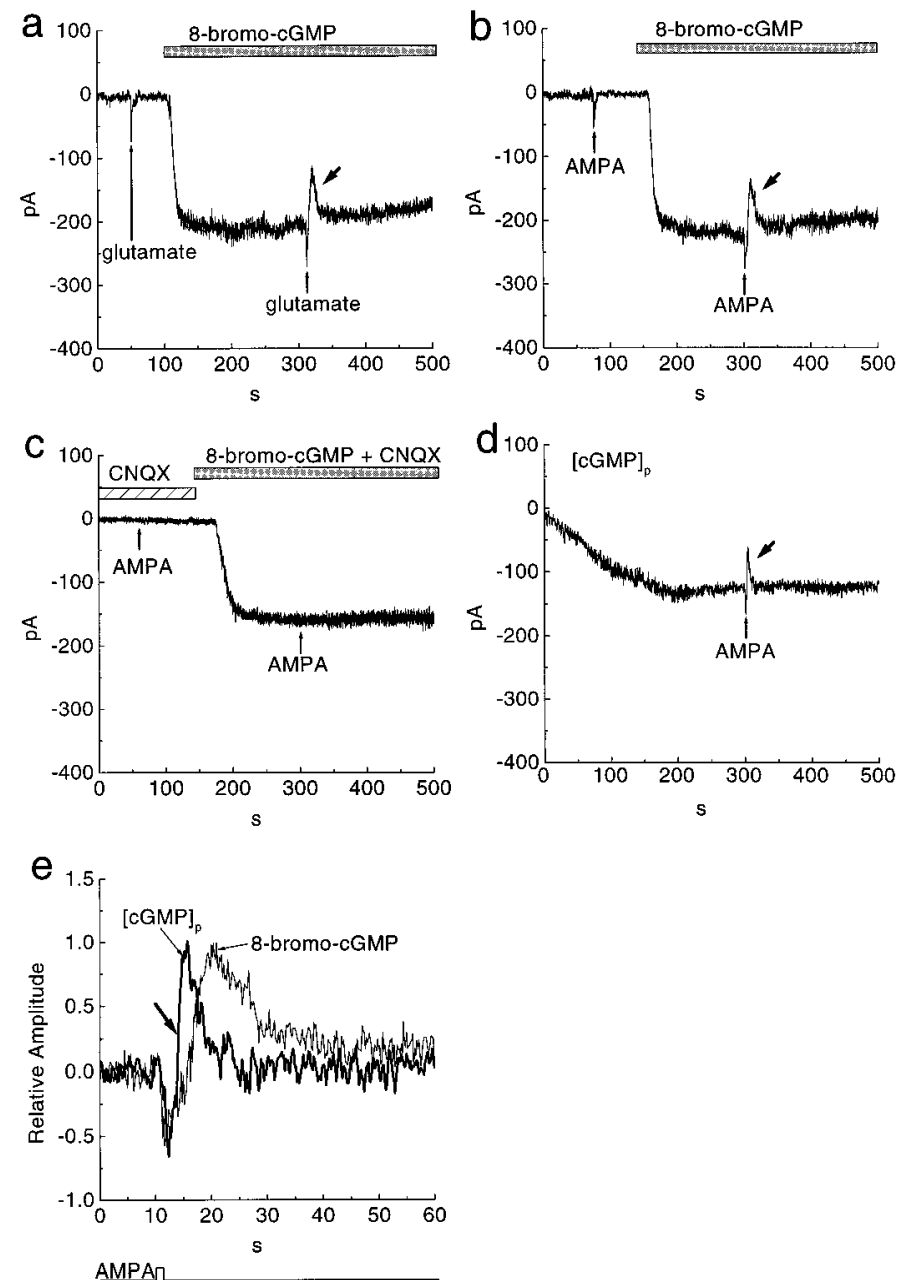

Figure 1. Stimulation of an AMPA receptor reduced a sustained inward current caused by cGMP. $a, b$, Puffer application of $100 \mu \mathrm{M}$ glutamate for $1 \mathrm{sec}$ (thin arrows) or $100 \mu \mathrm{M}$ AMPA induced a fast transient inward current. Superfusion with $1 \mathrm{~mm}$ 8-bromo-cGMP (bars) activated a sustained inward current that was reduced (thick arrows) by puffer application of glutamate or AMPA. $c$, Application of $100 \mu \mathrm{M}$ AMPA failed to reduce the 8-bromo-cGMP-induced sustained current in the solution containing $100 \mu \mathrm{M}$ CNQX. $d$, Intracellular dialysis with $1 \mathrm{~mm}$ cGMP caused a slowly developing inward current that was also reduced (thick arrow) by puffer application of $100 \mu \mathrm{M}$ AMPA. Whole-cell recording established at $t=0$. e , Normalized responses to AMPA application plotted from $b$ and $d$ on a faster scale. All cells were held at $-50 \mathrm{mV}$.

bath-applied at $1 \mathrm{~mm}$ to a ganglion cell voltage-clamped at -50 $\mathrm{mV}$, there was a sustained inward current $(217 \pm 6 \mathrm{pA}$; mean \pm SEM) (Fig. 1a). This current disappeared in normal Ringer's solution. The same current was obtained with another membranepermeant analog of cGMP [1 mM 8-p-chlorophenylthio-cGMP, which strongly resists hydrolysis by phosphodiesterase (PDE)] in the bath and also when the recording pipette contained cGMP (Fig. $1 d)$. A permeant analog of cAMP was ineffective $(n=4)$. The cGMP-gated current was observed in approximately half of the cells (37 of 73).

When the sustained cGMP-gated current was induced by 8-bromo-cGMP, a puff of $100 \mu \mathrm{M}$ glutamate evoked a biphasic response (Fig. 1a). First, there was a transient inward current, as expected for direct gating of an ionotropic receptor; then, there was a brief reduction of the sustained inward current $(41 \pm 7 \%$; $n=5$ ) (Fig. 1a). The same biphasic response was evoked by
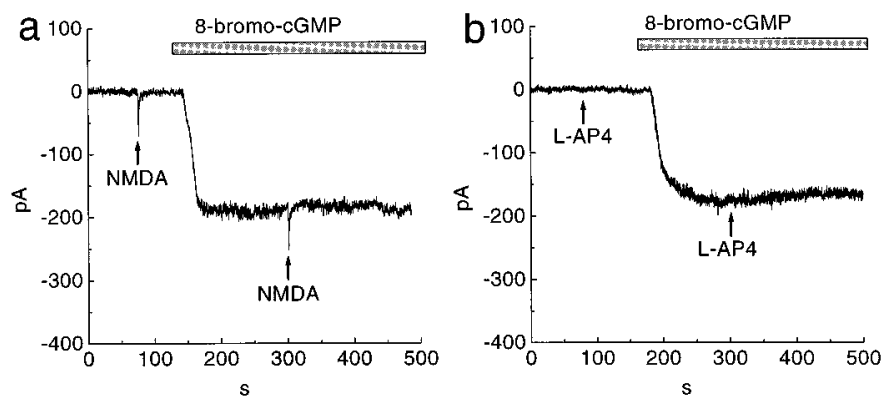

Figure 2. The sustained inward current caused by cGMP was unaffected by NMDA and mGluR agonists. $a$, Application of $100 \mu \mathrm{M}$ NMDA for 1 sec from a puffer pipette (arrows) failed to reduce the 8-bromo-cGMPinduced sustained current. $b$, Application of $100 \mu \mathrm{M} \mathrm{L}-\mathrm{AP}-4$ (arrows) had no effect on a cell before or during superfusion of $1 \mathrm{~mm}$ 8-bromo-cGMP. All cells were held at $-50 \mathrm{mV}$.

AMPA (10-100 $\mu \mathrm{M})$ (Fig. $1 b)$ and by the AMPA receptor agonist kainate $(10 \mu \mathrm{M} ; n=3)$. The amplitude of the second phase (reduced inward current) was similar for $100 \mu \mathrm{M}$ AMPA and 10 $\mu \mathrm{M}$ kainate $(38 \pm 6$ and $34 \pm 11 \%$, respectively, with 8-bromocGMP). The amplitude of the second phase was also similar for $100 \mu \mathrm{M}$ by AMPA and $100 \mu \mathrm{M}$ glutamate $(54 \pm 7$ and $55 \pm 8 \%$, respectively, with cGMP). However, when the sustained inward current was induced by 8 - $p$-chlorophenylthio-cGMP, $100 \mu \mathrm{M}$ AMPA did not reduce the second phase of the response $(3 \pm 1 \%$; $n=3)$. The reduction by AMPA of the inward current was faster (Fig. 1e, thick arrow) when the sustained current was induced by cGMP rather than by 8-bromo-cGMP. The latency to maximal reduction after the AMPA puff was $4 \pm 2 \mathrm{sec}$ for cGMP and $11 \pm$ $3 \mathrm{sec}$ for 8-bromo-cGMP.

To identify which type of glutamate receptor reduced the inward current, we applied various agonists and antagonists of the ionotropic receptors. CNQX $(100 \mu \mathrm{M})$, an antagonist of both AMPA and kainate subtypes, diminished the effect of AMPA $(n=4)$ (Fig. 1c). Furthermore, GYKI-52466 (100 $\mu \mathrm{M})$, a specific antagonist of the AMPA receptor (Donevan and Rogawski, 1993), also diminished the effect of kainate $(n=3)$. Therefore, kainate receptors are probably not involved. The AMPA effects observed here, both the conventional transient inward current and the novel reduction of the sustained inward current, seem to desensitize rather little, as reported by others for AMPA responses of bipolar and ganglion cells in mammalian retina (Cohen et al., 1994; Sasaki and Kaneko, 1996). Finally, NMDA, applied as a $100 \mu \mathrm{M}$ puff, evoked a monophasic inward current but did not reduce the inward current $(n=4)$ (Fig. $2 a)$. Thus, whatever causes this brief reduction of the inward current, it is apparently triggered specifically by the AMPA receptor.

To test whether a metabotropic glutamate receptor (mGluR) might reduce the inward current, we applied mGluR agonists. These included L-AP-4 $(n=4)$ (Fig. $2 b)$ and ACPD $(n=3)$. Although these compounds evoke large currents in ON bipolar cells (Nawy and Jahr, 1990; Shiells and Falk, 1990; Yamashita and Wässle, 1991; Tian and Slaughter, 1994) at the concentration used $(100 \mu \mathrm{M})$, they did not affect the inward cGMP-gated current. Furthermore, mGluR antagonists MCPG and CPPG, both applied at $300 \mu \mathrm{M}$, did not affect the AMPA-evoked reduction of the steady inward current $(n=4)$. We conclude that the reduction by AMPA of the sustained inward current is not caused by activation of an mGluR.

If the reduction by AMPA of the sustained inward current 

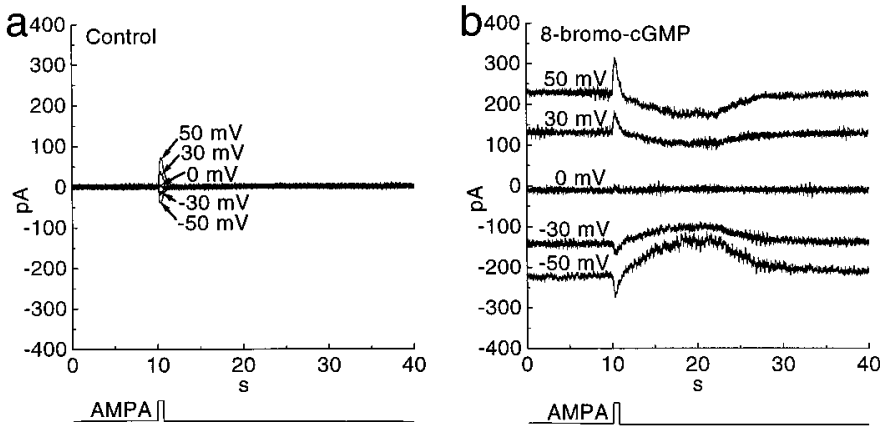

C

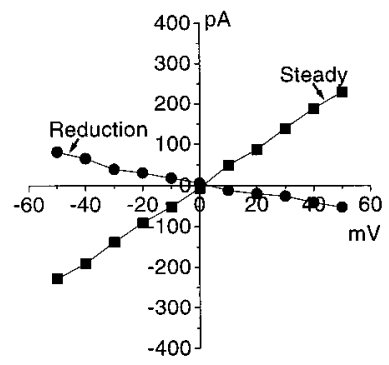

Figure 3. AMPA-induced reduction of current reversed at the same potential as the cGMP-gated current. $a$, Brief current evoked by a puff of $100 \mu \mathrm{M}$ AMPA was inward at negative potentials and reversed at $0 \mathrm{mV}$. $b$, Same cell in Ringer's solution containing $1 \mathrm{~mm}$ 8-bromo-cGMP. Slow transient current evoked by AMPA was outward at negative potentials and reversed at $0 \mathrm{mV} . c, I-V$ curves of the steady and reduced cGMPgated currents. Both currents reversed at $2 \mathrm{mV}$. These experiments suggest that AMPA actually suppresses the cGMP-gated current.

results from closing the cGMP-gated channel, both the reduction and the sustained current should have the same reversal potential. The reduction by AMPA of the sustained inward current was outward at negative potentials and reversed at $0 \mathrm{mV}$ (Fig. $3 b$ ). Similarly, the sustained current induced by 8-bromo-cGMP was inward at negative potentials and also reversed at approximately $0 \mathrm{mV}$ (Fig. 3b). Similar values were obtained from four cells ( $3 \pm$ $4 \mathrm{mV}$ ), consistent with a previous report (Ahmad et al., 1994). Thus, both the cGMP-gated current and its AMPA-induced reduction reversed at the same membrane potential $(n=4)$ (Fig. $3 c$ ), suggesting that AMPA suppresses the cGMP-gated current. If so, AMPA should also suppress the sustained cGMP-gated current induced by the NO donor, sodium nitroprusside, and we confirmed this $(n=4)$ (Fig. 4$)$.

To investigate how the AMPA receptor suppresses the cGMPgated current, we considered a role for $\mathrm{Ca}^{2+}$ as a second messenger (Kaupp and Koch, 1992; Nakanishi, 1992; Hille, 1994; Koutalos and Yau, 1996). If $\mathrm{Ca}^{2+}$ entering through the AMPA receptor was involved, removing extracellular $\mathrm{Ca}^{2+}$ should abolish the suppression. However, with $5 \mathrm{~mm}$ EGTA or BAPTA in a recording pipette, AMPA puffed onto a ganglion cell in $\mathrm{Ca}^{2+}$ free Ringer's solution evoked the usual suppression of the cGMPgated current $(n=6)$ (Fig. 5a). AMPA $(100 \mu \mathrm{M})$ reduced the current by $41 \pm 7 \%$, which was similar to that in control Ringer's solution $(38 \pm 6 \%)$. The latency $(12 \pm 4 \mathrm{sec})$ to maximal current reduction after the AMPA puff was also similar to the control $(11 \pm 3 \mathrm{sec})$. When all permeant cations were removed from the medium, 8-bromo-cGMP induced no inward current at negative potentials; however, it did induce a sustained outward current at positive potentials, and this current was suppressed by AMPA.

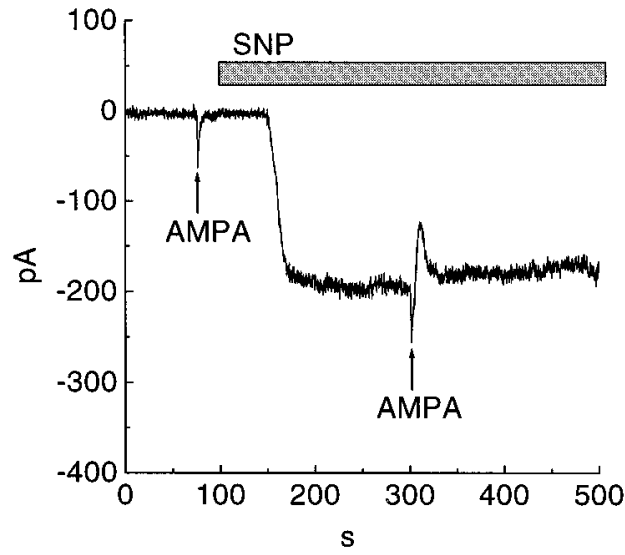

Figure 4. Superfusion with $100 \mu \mathrm{M}$ sodium nitroprusside $(S N P)$ activated a sustained inward current reduced by puffer application of $100 \mu \mathrm{M}$ AMPA for $1 \mathrm{sec}$ (arrows). A cell was held at $-50 \mathrm{mV}$.
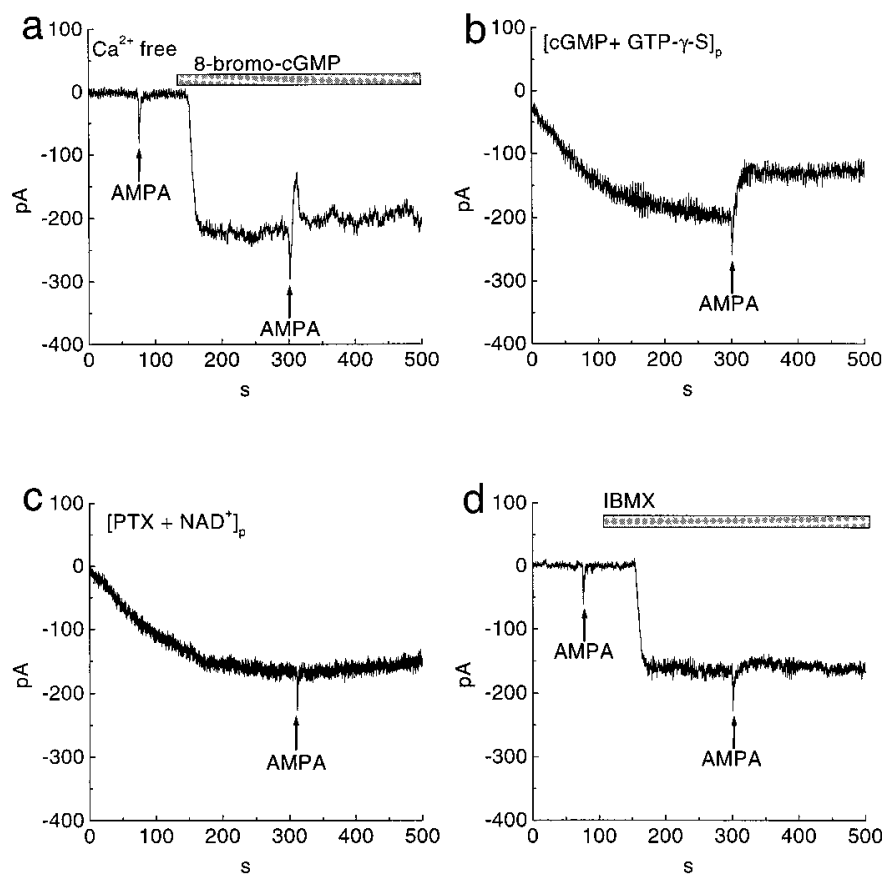

Figure 5. The suppression by AMPA of the cGMP-gated current is mediated by a G-protein that activates PDE. $a$, Application of $100 \mu \mathrm{M}$ AMPA (arrows) suppressed the 8-bromo-cGMP-induced sustained current in the $\mathrm{Ca}^{2+}$-free solution. The recording pipette contained $5 \mathrm{mM}$ EGTA. $b$, Dialysis of a cell with $1 \mathrm{mM}$ cGMP and $100 \mu \mathrm{M}$ GTP- $\gamma$-S produced an inward current. An AMPA puff (arrow) evoked a brief inward current and suppressed the sustained inward current irreversibly. Whole-cell recording established at $t=0 . c$, Dialysis of a cell with pertussis toxin $(P T X ; 1 \mu \mathrm{g} / \mathrm{ml})$ and $\mathrm{NAD}^{+}(1 \mathrm{~mm})$ also produced an inward current. An AMPA puff (arrow) evoked a brief inward current but failed to suppress the sustained inward current. $d$, Superfusion with 100 $\mu \mathrm{M}$ IBMX (bar) activated an inward current. An AMPA puff (arrows) also failed to suppress the inward current induced by IBMX. All cells were held at $-50 \mathrm{mV}$.

Thus, neither $\mathrm{Ca}^{2+}$ nor $\mathrm{Na}^{+}$influx is required for the suppression, and we sought another mechanism.

We considered a role for a G-protein, possibly the $\mathrm{G}_{\mathrm{i}}$ family $\left(\mathrm{G}_{\mathrm{i}}\right.$ or $G_{o}$ ), because AMPA can stimulate $G_{i}$ (Wang et al., 1997) and because the inner plexiform and ganglion cell layers are immunoreactive for $\mathrm{G}_{\mathrm{i} / \mathrm{o}}$ (Terashima et al., 1987; Vardi et al., 1993; 
Oguni et al., 1996). To test for a G-protein activity, we used $1 \mathrm{~mm}$ cGMP in the patch pipette to cause a sustained inward current (as in Fig. $1 d$ ) but also included $100 \mu \mathrm{M}$ GTP- $\gamma$-S. An AMPA puff induced the expected inward transient, followed by suppression of the sustained current. However, when the AMPA dissipated, the sustained current was not restored; rather, the suppression became essentially irreversible $(n=4)$ (Fig. $5 b)$. This would be expected if an activated G-protein had bound GTP- $\gamma$-S because this GTP analog does not hydrolyze. In a separate experiment with $1 \mathrm{~mm}$ cGMP in the pipette, we used $500 \mu \mathrm{M}$ GDP- $\beta$-S to competitively block G-protein activation (Nawy and Jahr, 1990). This produced a sustained inward current, which AMPA failed to suppress $(n=3)$.

Evidence that the G-protein species might be $\mathrm{G}_{\mathrm{i} / \mathrm{o}}$ came from experiments with pertussis toxin. Pertussis toxin ADP ribosylates $\mathrm{G}_{\mathrm{i} / \mathrm{o}}$ (Milligan, 1988), thereby blocking its downstream effect. Dialyzing a cell with pertussis toxin and $\mathrm{NAD}^{+}$(omitting cGMP) produced a sustained inward current, which AMPA also failed to suppress $(n=5)$ (Fig. $5 c)$. When $\mathrm{NAD}^{+}$was omitted, pertussis toxin alone failed to produce the effect $(n=3)$, suggesting that ADP-ribosylation by pertussis toxin of $\mathrm{G}_{\mathrm{i} / \mathrm{o}}$ induced the inward current. This effect of pertussis toxin is consistent with previous results with ON bipolar cell (Shiells and Falk, 1992). Cholera toxin, which ADP ribosylates $G_{s}$, caused no inward current until 8-bromo-cGMP was added, and then the usual suppression was observed $(n=3)$. Because the cGMP-gated current seems to be suppressed by activating $G_{i / o}$, we considered possible intermediate effectors.

PDE seemed a natural candidate, by analogy with photoreceptors and certain bipolar cells in which a G-protein activates PDE to suppress a cGMP-gated current (Yau and Baylor, 1989; Kaupp and Koch, 1992; Lamb and Pugh, 1992; Koutalos and Yau, 1996). Furthermore, as noted, suppression by AMPA of the inward current was faster when the sustained current was induced by cGMP rather than by 8-bromo-cGMP (Fig. 1e). This would be expected from a PDE mechanism because the brominated analog hydrolyzes slowly (Wei et al., 1998). The amplitude of the current suppression was approximately similar for both compounds. Although this might seem contradictory, the sluggish hydrolysis of PDE of 8-bromo-cGMP may be counterbalanced by its sixfold higher affinity for 8-bromo versus native cGMP (Wei et al., 1998). These considerations led us to try inhibitors of PDE.

We found, as first reported by Ahmad et al. (1994), that the PDE inhibitor IBMX induced a sustained inward current in a ganglion cell that expresses the cGMP-gated channel $(n=4)$ (Fig. 5d). This implies that the cell also expresses an active PDE that regulates intracellular cGMP. With IBMX in the bath, an AMPA puff failed to suppress the inward current $(n=4)$ (Fig. $5 d$ ). We obtained the same result using a selective inhibitor of cGMP phosphodiesterase, zaprinast $(n=3)$. Presumably AMPA was ineffective because $G_{i / o}$ could not activate PDE. The suppression by AMPA of the cGMP-gated current was observed when, to the bath containing 8-bromo-cGMP, we added $1 \mathrm{~mm}$ methylene blue, which completely inhibits guanylyl cyclase $(n=$ 4) (Danziger et al., 1993; Fratelli et al., 1995; Stuart-Smith et al., 1998). This result suggests that the suppression does not involve modulation of the cyclase.

\section{DISCUSSION}

In ganglion cells that express the cGMP-gated channel, AMPA acts in two ways: (1) transiently opens a cation channel; and (2) activates a G-protein that, via PDE, reduces [cGMP] to suppress

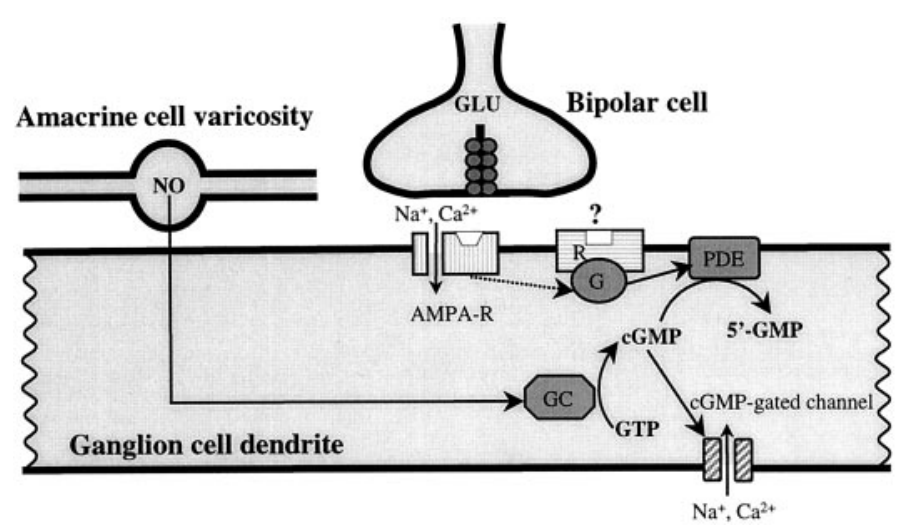

Figure 6. Model explains how the AMPA receptor in retinal ganglion cells might suppress the cGMP-gated current. NO released from amacrine cells raises [cGMP] (Sagar, 1986), inducing the cGMP-gated current (Ahmad et al., 1994). Ganglion cells express $\mathrm{G}_{\mathrm{i} / \mathrm{o}}$-coupled metabotropic receptors (shown by a question mark), such as $\mathrm{GABA}_{\mathrm{B}}$ (Zhang et al., 1997) and $D_{2}$-dopamine receptor (Djamgoz and Wagner, 1992). Unidentified link is shown with a broken arrow. GLU, Glutamate; $R$, G-protein-coupled receptor; $G, \mathrm{G}_{\mathrm{i}}$ or $\mathrm{G}_{\mathrm{o}}$ protein.

a cGMP-gated current (Fig. 6). This second effect of AMPA cannot be attributed to activation of a genuine $\mathrm{mGluR}$ receptor because agonists and antagonists of mGluRs were ineffective. We feel confident that a PDE is involved because the effect was abolished by inhibitors of PDE and also by the analog of cGMP, which strongly resists hydrolysis. In short, this AMPA receptor seems to exhibit both ionotropic and metabotropic activities. This conclusion fits biochemical evidence that an AMPA receptor in cortex can activate a G-protein to modulate cAMP (Wang et al., 1997) and that a kainate receptor in hippocampus can activate a G-protein to modulate yet another biochemical cascade (phospholipase C; Rodriguez-Moreno and Lerma, 1998). Thus, metabotropic effects of ionotropic glutamate receptors may prove to be both widespread and diverse.

Given that the suppression by AMPA of the cGMP-gated current acts via a non-NMDA ionotropic glutamate receptor, can the family be identified? Probably, it is the AMPA family (GluR1-4) because of the following: (1) ganglion cells express mRNA for these subunits most strongly (Hamassaki-Britto et al., 1993); (2) the concentrations of AMPA $(10-100 \mu \mathrm{M})$ were insufficient to activate native kainate receptors (Lerma et al., 1993; Clarke et al., 1997; Huettner, 1997); and (3) the effect was blocked by GYKI-52466, which is relatively specific for AMPA receptors. Which particular AMPA subunits (GluR1-4) suppress the cGMP-gated current cannot be determined until their specific agonists and antagonists become available.

AMPA receptors on CNS neurons desensitize rapidly (Colquhoun et al., 1992; Raman and Trussell, 1992; Seeburg, 1993). Therefore, it surprised us that, as in previous reports on mammalian retina (Cohen et al., 1994; Sasaki and Kaneko, 1996), puff-applied AMPA causes little obvious desensitization. However, the time course of our puff application is slow compared with the rapid-flow method (Colquhoun et al., 1992; Raman and Trussell, 1992) used to study desensitization. If our ganglion cells desensitize in milliseconds, we would not see the effect. Another possibility is that ganglion cells might express an alternatively spliced "flip" module of the AMPA receptor, which desensitizes more slowly than a receptor containing both "flip" and "flop" 
modules (Sommer et al., 1990; Seeburg, 1993). Finally, a heteromer of AMPA subunits (GluR1-4) and kainate subunits (GluR5-7 and KA1/2) might resist desensitization.

How the AMPA receptor couples to the G-protein remains to be established. Seven transmembrane receptors, including the mGluRs, contain a cytoplasmic tail with a conserved amino acid sequence that binds the G-protein (Nakanishi, 1992; Hille, 1994; Riedel, 1996; Pass, 1998). However, the AMPA receptor is assembled from hetero-oligomers that lack such a sequence (Sommer et al., 1990; Nakanishi, 1992; Seeburg, 1993; Pass, 1998), so the AMPA receptor probably does not affect the G-protein directly. Because there are now three examples in which AMPA and kainate receptor families use a G-protein to trigger a biochemical cascade (adenylyl cyclase, Wang et al., 1997; phospholipase C, Rodriguez-Moreno and Lerma, 1998; PDE, present study), it will be important to identify the coupling mechanism.

Approximately half of the recorded ganglion cells expressed the cGMP-gated current, and all of these showed the AMPAinduced suppression. We identified ganglion cells in the slice by their location (ganglion cell layer) and large size (compared with displaced amacrine cells) but did not study their morphology. It will now be interesting to determine which type(s) of ganglion cell express this mechanism and to learn its role in visual processing. Possibly, NO amacrine cells increase the cGMP-gated inward current of a ganglion cell and thus enhance spiking. In a preliminary experiment, we indeed observed that 8-bromocGMP had this effect. Glutamate from bipolar cells can suppress the cGMP-gated current to briefly curtail these extra spikes. Thus, the metabotropic action of the AMPA receptor might contribute to suppress excitation from the NO amacrine cells. Naturally, there are other possibilities, but this one emphasizes what may be a general mechanism in many brain regions: that glutamate can antagonize a key excitatory effect of NO.

\section{REFERENCES}

Ahmad I, Leinders-Zufall T, Kocsis JD, Shepherd GM, Zufall F, Barnstable CJ (1994) Retinal ganglion cells express a cGMP-gated cation conductance activatable by nitric oxide donors. Neuron 12:155-165.

Aizenman E, Frosch MP, Lipton SA (1988) Responses mediated by excitatory amino acid receptors in solitary retinal ganglion cells from rat. J Physiol (Lond) 396:75-91.

Clarke VR, Ballyk BA, Hoo KH, Mandelzys A, Pellizzari A, Bath CP, Thomas J, Sharpe EF, Davies CH, Ornstein PL, Schoepp DD, Kamboj RK, Collingridge GL, Lodge D, Bleakman D (1997) A hippocampal GluR5 kainate receptor regulating inhibitory synaptic transmission. Nature 389:599-603.

Cohen ED, Zhou ZJ, Fain GL (1994) Ligand-gated currents of $\alpha$ and $\beta$ ganglion cells in the cat retinal slice. J Neurophysiol 72:1260-1269.

Coleman PA, Miller RF (1998) Do $N$-methyl-D-aspartate receptors mediate synaptic responses in the mudpuppy retina? J Neurosci 8:4728-4733.

Colquhoun D, Jonas P, Sakmann B (1992) Action of brief pulses of glutamate on AMPA/kainate receptors in patch from different neurons of rat hippocampal slices. J Physiol (Lond) 458:261-287.

Danziger RS, Star RA, Matsumoto S, Coca-Prados M, DeSantis L, Pang IH (1993) Characterization of soluble guanylyl cyclase in transformed human non-pigmented epithelial cells. Biochem Biophys Res Commun 195:958-962.

Djamgoz MB, Wagner HJ (1992) Localization and function of dopamine in the adult vertebrate retina. Neurochem Int 20:139-191.

Donevan SD, Rogawski MA (1993) GYKI-52466, a 2,3-benzodiazepine, is a highly selective, noncompetitive antagonist of AMPA/kainate receptor responses. Neuron 10:51-59.

Fratelli M, Delgado R, Zinetti M, Galli G, Rolland Y, Ghezzi (1995)
Chlorpromazine inhibits nitric oxide-mediated increase in intracellular cGMP in a mouse teratocarcinoma cell line. Inflamm Res 44:287-290.

Hamassaki-Britto DE, Hermans-Borgmeyer I, Heinemann S, Hughes TE (1993) Expression of glutamate receptor genes in the mammalian retina: the localization of GluR1 to GluR7 mRNAs. J Neurosci 13:1888-1898.

Hamill OP, Marty A, Neher E, Sakmann B, Sigworth FJ (1981) Improved patch-clamp techniques for high resolution current recording from cells and cell-free membrane patches. Pflügers Arch 391:85-100.

Hille B (1994) Modulation of ion-channel function by G-protein-coupled receptors. Trends Neurosci 17:531-536.

Huettner JE (1997) Functional properties of kainate receptors. In: The ionotropic glutamate receptors (Monaghan DT, Wenthold RJ, eds), pp 265-283. Totowa, NJ: Humana.

Kaupp UB, Koch K-W (1992) Role of cGMP and $\mathrm{Ca}^{2+}$ in vertebrate photoreceptor excitation and adaptation. Annu Rev Neurosci 54:153-175.

Koutalos Y, Yau K-W (1996) Regulation of sensitivity in vertebrate rod photoreceptors by calcium. Trends Neurosci 19:73-81.

Lamb TD, Pugh Jr EN (1992) G-protein cascades: gain and kinetics. Trends Neurosci 15:291-298.

Leinders-Zufall T, Rand MN, Waxman SG, Kocsis JD (1994) Differential role of two $\mathrm{Ca}^{2+}$-permeable non-NMDA glutamate channels in rat retinal ganglion cell: kainate-induced cytoplasmic and nuclear $\mathrm{Ca}^{2+}$ signals. J Neurophysiol 72: 2503-2516.

Lerma J, Paternain AV, Naranjo JR, Mellstrom B (1993) Functional kainate selective glutamate receptor in cultured hippocampal neurons. Proc Natl Acad Sci USA 90:11688-11692.

Matsui K, Hosoi N, Tachibana M (1998) Excitatory synaptic transmission in the inner retina: paired recording of bipolar cells and neurons of the ganglion cell layer. J Neurosci 18: 4500-4510.

Milligan G (1988) Techniques used in the identification and analysis of function of pertussis toxin-sensitive guanine nucleotide binding proteins. Biochem J 255:1-13.

Mittman S, Taylor WR, Copenhagen DR (1990) Concomitant activation of two types of glutamate receptor mediates excitation of salamander retinal ganglion cells. J Physiol (Lond) 428:175-197.

Nakanishi S (1992) Molecular diversity of glutamate receptors and implications for brain function. Science 258:597-603.

Nawy S, Jahr CE (1990) Suppression by glutamate of cGMP-activated conductance in retinal bipolar cells. Nature 346:269-271.

Oguni M, Shinohara H, Asano T, Kato K, Setogawa T (1996) Ontogeny of GTP-binding proteins, $G_{i}$ and $G_{(o)}$, in rat retina. Histochem Cell Biol 106: 235-240.

Pass Y (1998) The macro- and microarchitectures of the ligand-binding domain of glutamate receptors. Trends Neurosci 21:117-125.

Raman IM, Trussell LO (1992) The kinetics of the response to glutamate and kainate in neurons of the avian cochlear nucleus. Neuron 9:173-186.

Riedel G (1996) Function of metabotropic glutamate receptors in learning and memory. Trends Neurosci 19:219-224.

Rodriguez-Moreno A, Lerma J (1998) Kainate receptor modulation of GABA release involves a metabotropic function. Neuron 20:1211-1218.

Sagar S (1986) NADPH-diaphorase histochemistry in the rabbit retina. Brain Res 373:153-158.

Sandell JH (1985) NADPH diaphorase cells in the mammalian inner retina. J Comp Neurol 238:466-472.

Sasaki T, Kaneko A (1996) L-glutamate-induced responses in OFF-type bipolar cells of the cat retina. Vision Res 36:787-795.

Seeburg PH (1993) The molecular biology of mammalian glutamate receptor channels. Trends Neurosci 16:359-365.

Shiells RA, Falk G (1990) The glutamate receptor of rod bipolar cells are linked to a cyclic GMP cascade via a G-protein. Proc R Soc Lond B Biol Sci 242:91-94.

Shiells RA, Falk G (1992) The glutamate-receptor linked cGMP cascade of retinal on-bipolar cell is pertussis and cholera toxin-sensitive. Proc R Soc Lond B Biol Sci 247:17-20.

Sommer B, Keinanen K, Verdoorn TA, Wisden W, Burnashev N, Herb A, Kohler M, Takagi T, Sakmann B, Seeburg PH (1990) Flip and flop: a cell-specific functional switch in glutamate-operated channels of the CNS. Science 249:1580-1585.

Stuart-Smith K, Warner DO, Jones KA (1998) The role of cGMP in the relaxation to nitric oxide donors in airway smooth muscle. Eur J Pharmacol 341:225-233.

Taylor WR, Chen E, Copenhagen DR (1995) Characterization of spon- 
taneous excitatory synaptic currents in salamander retinal ganglion cells. J Physiol (Lond) 486:207-221.

Terashima T, Katada T, Oinuma M, Inoue Y, Ui M (1987) Immunohistochemical localization of guanine nucleotide-binding protein in rat retina. Brain Res 410:97-100.

Tian N, Slaughter MM (1994) Pharmacological similarity between the retinal APB receptor and the family of metabotropic glutamate receptors. J Neurophysiol 71:2258-2268.

Vardi N, Matesic DF, Manning DR, Liebman PA, Sterling P (1993) Identification of a G-protein in depolarizing rod bipolar cells. Vis Neurosci 10:473-478.

Wang Y, Small DL, Stanimirovic DB, Morley P, Durkin JP (1997) AMPA receptor-mediated regulation of a $\mathrm{G}_{\mathrm{i}}$-protein in cortical neurons. Nature 389:502-504.

Wei J-Y, Cohen ED, Genieser H-G, Barnstable CJ (1998) Substituted
cGMP analogs can act as selective agonists of the rod photoreceptor cGMP-gated cation channel. J Mol Neurosci 10:53-64.

Werblin FS (1978) Transmission along and between rods in the tiger salamander retina. J Physiol (Lond) 280:449-470.

Yamashita M, Wässle H (1991) Response of rod bipolar cells isolated from the rat retina to the glutamate agonist 2-amino-4-phosphonobutyric acid (APB). J Neurosci 11:2372-2382.

Yau K-W, Baylor DA (1989) Cyclic GMP-activated conductance of retinal photoreceptor cells. Annu Rev Neurosci 12:289-327.

Zhang D, Sucher NJ, Lipton SA (1995) Co-expression of AMPA/kainate receptor-operated channels with high and low $\mathrm{Ca}^{2+}$ permeability in single rat retinal ganglion cells. Neuroscience 67: 177-188.

Zhang J, Shen W, Slaughter MM (1997) Two metabotropic $\gamma$-aminobutyric acid receptors differentially modulated calcium currents in retinal ganglion cells. J Gen Physiol 110:45-58. 